\title{
Islam Moderat dan Islam Radikal dalam Perspektif Generasi Milenial
}

\section{Kota Surabaya}

\author{
Abdul Djalal \\ Prodi Ilmu al-Qur'an dan Tafsir, Fakultas Ushuluddin Dan Filsafat, \\ UIN Sunan Ampel Surabaya \\ abduldjala181@gmail.com \\ M. Syamsul Huda \\ Prodi Aqidah dan Filsafat Islam, Fakultas Ushuluddin Dan Filsafat, \\ UIN Sunan Ampel Surabaya \\ msyamsulhuda@gmail.com
}

Naskah diterima: 3 April 2020; direvisi: 17 Juli 2020; disetujui: 18 Juli 2020

\begin{abstract}
This paper examines the results of several previous studies that took formal education as an object of research with respondents from students and teachers in the Jakarta, Bandung and Yogyakarta regions, who agreed to a change in state ideology from Pancasila to the Islamic Khilafah and acts of violence in religion. As a test tool, the authors offer research objects to milenials in Surabaya with formal and non-formal educational backgrounds and social settings of various professional backgrounds, education, and ages between 17 and 30 years and with in-depth observation methods and interviews with FGD techniques (Focus Group Discussion) on 13 young people of the city of Surabaya on four regions in the city of Surabaya. The results of this study indicate; first, Milenial generation narratives about moderate Islam show religious experiences that are relaxed, light, peaceful, and flexible and radical Islam as Islamic behavior that cannot adapt to its environment. The source of the reference shifts from book literacy to digital literacy by utilizing social media content, Instagram, and Youtube. Third. the figure and inspiration also changed from the figure of the ulama to the figures who perform 'hijrah', both artists and young clerics, and entertaiment products that utilize digital media.
\end{abstract}

Keywords: millennial generation, moderate Islam, radical Islam, text, context

\begin{abstract}
Abstrak
Paper ini menguji hasil beberapa penelitian sebelumnya yang mengambil pendidikan formal sebagai obyek penelitian dengan responden para pelajar, mahasiswa, dan guru di daerah Jakarta, Bandung, dan Yogyakarta, yang menyetujui perubahan ideologi negara dari Pancasila ke khilafah Islamiyah serta tindakan kekerasan dalam beragama. Sebagai alat uji, penulis menawarkan obyek penelitian pada para generasi milenial di kota Surabaya dengan latar belakang pendidikan formal dan non formal dan setting sosial berbagai latar belakang profesi, pendidikan, serta usia antara 17 sampai 30 tahun dan dengan metode observasi mendalam dan wawancara dengan teknik FGD (Focus Group Discussion) pada 13 anak muda kota Surabaya pada empat wilayah di kota Surabaya. Hasil penelitian ini menunjukkan; Pertama, narasi generasi milenial tentang Islam moderat menunjukkan pada pengalaman keagamaan yang bercorak santai, ringan, damai dan fleksibel dan Islam radikal sebagai perilaku Islam yang tidak bisa beradaptasi dengan lingkungannya. Kedua, sumber referensinya bergeser dari literasi buku ke literasi digital dengan memanfaatkan konten media sosial, Instagram, dan Youtube. Ketiga, figur dan inspiratornya juga berubah dari sosok ulama ke para tokoh
\end{abstract}


hijrah, baik artis maupun ustadz muda produk entertaiment yang memanfaatkan media digital.

Kata kunci: generasi milenial, Islam moderat, Islam radikal, teks, konteks

\section{Pendahuluan}

Topik generasi milenial saat ini menjadi pusat perhatian oleh banyak kalangan di dunia dalam berbagai perspektif. Peneliti kepemudaan sering mengelompokkan generasi yang lahir di antara tahun 1980an sampai 2000an sebagai generasi milenial yang saat ini berusia di kisaran 18-38 tahun. Dikatakan pula bahwa generasi milenial adalah generasi muda masa kini yang saat ini berusia di kisaran 15 - 34 tahun. Batas usia generasi milenial tersebut identik dengan kategori Youth (pemuda) oleh UNESCO yaitu mulai usia 15-30 tahun. (Pilcher, 1993)

Studi tentang generasi milenial sudah banyak dilakukan. Studi yang dilakukan oleh Boston Consulting Group (BCG) bersama University of Berkley tahun 2011 mengambil tema American Milenials: Deciphering the Enigma Generation. Tahun sebelumnya, 2010, Pew Research Center juga merilis laporan riset dengan judul Milenials: A Portrait of Generation Next. (France, 2007)

Di Indonesia, penelitian yang sama juga dilakukan oleh Alvara Research Center pada tahun 2014, yang menunjukkan bahwa generasi yang lebih muda, antara usia 15-24 tahun lebih menyukai topik pembicaraan yang terkait musik/film, olah raga, teknologi, dan terutama ketergantungan mereka terhadap koneksi internet sangat tinggi. (France, 2007) Sementara generasi yang berusia antara 25-34 tahun lebih variatif dalam menyukai topik yang mereka perbincangkan, termasuk sosial, politik, ekonomi, dan keagamaan. Di samping penelitian ini, terdapat beberapa penelitian lain yang mengangkat tema moderasi dan radikalisme para pemuda. Dalam rangka meraih gelar sarjana di UIN Sunan Kalijogo pada tahun 2011, Saifuddin melakukan penelitian bertema Radikalisme Islam di Kalangan Mahasiswa (Sebuah Metamorfosa Baru). Hasil penelitian ini menunjukkan bahwa gerakan radikalisme Islam di Indonesia bukan hanya didominasi oleh kalangan penganut Islam awam, namun peran baru para mahasiswa juga mempunyai peran aktif menggeser peran masyarakat Islam awam. Keberhasilan peran baru mahasiswa tersebut tidak lepas dari strategi para fundamentalis dalam melakukan kaderisasi secara intelektual melalui indoktrinasi ideologis sehingga mahasiswa sulit terlepas dari kelompok ini. Ira Rosmaya dan tim dari Universitas Bhayangkara juga melakukan penelitian tentang Persepsi Mahasiswa Terhadap Radikal Terorisme Melalui Website Dan Sosial Media, pada tahun 2016. Hasil 
penelitian ini menunjukkan bahwa kelompok radikal memanfaatkan media sosial karena mahasiswa dalam aktivitas akademiknya tidak lepas dengan dunia maya. Akibatnya adalah banyak mahasiswa yang terpapar oleh paham radikalis.

Di sisi lain, di Indonesia, diskusi tentang keberagamaan menemukan momentum baru pada masa pasca reformasi yang ditandai dengan terbukanya kran demokratisasi. Hampir seluruh kelompok keagamaan mendapatkan ruang untuk speak up, baik yang dianggap kelompok liberal, moderat, maupun radikal. Dari ketiga kelompok keagamaan ini, kelompok radikal di kalangan umat Islam lebih menarik perhatian hingga saat ini. Hasil Survey Lembaga Kajian Islam dan Perdamaian dengan responden guru PAI dan siswa SMP seJadebotabek menunjukkan potensi radikal yang kuat di kalangan guru dan pelajar dengan indikasi resistensi yang lemah terhadap kekerasan atas nama agama, intoleransi, sikap eksklusif, serta keraguan terhadap ideologi Pancasila. (Lembaga Kajian Islam dan Perdamaian (LKIP), 2011)

Dari kajian dan penelitian tersebut di atas, terdapat ruang kosong yang belum dikaji lebih lanjut, terutama tentang persepsi generasi milenial yang berimbang antara Islam moderat dan Islam radikal pada urban city yang secara geografis mempunyai pandangan tersendiri, open mind, toleran pada hal-hal baru di antara masyarakat yang heterogen terhadap perubahan budaya dan pemikiran. Pemahaman terhadap Islam moderat dan Islam radikal menjadi bagian penting dari pemahaman generasi milenial yang menitikberatkan pada bagaimana memahami pemikiran dan dasar nalar dan etis yang digunakan oleh para pemuda muslim milenial di Kota Surabaya, dengan mengaju pada teori -teori penelitian kepemudaan antara lain teori identitas, teori transisi dan teori Positive Youth Develop (PYD).

Lokasi kota Surabaya menjadi menarik dipilih dalam penelitian ini karena ciri khas masyarakat Surabaya adalah mudah bergaul, gaya bicaranya sangat terbuka walaupun tampak seperti bertemperamen kasar, masyarakat Surabaya sangat demokratis, toleran dan senang menolong orang lain. Posisi strategis Kota Surabaya sebagai pusat kegiatan ekonomi masyarakat membuatnya selalu dinamis dan menjadi pusat aktivitas serta menjadi destinasi bagi banyak orang dari berbagai daerah. Jumlah penduduknya jelas akan semakin meningkat seiring pesona Kota Surabaya yang menjanjikan segala macam kemudahan. Akan tetapi, tantangan besar Kota Surabaya berikutnya ialah menyiapkan kehidupan yang layak. Kota Surabaya haruslah tetap menjadi rumah yang aman dan nyaman bagi penghuninya, terutama dalam keragaman kultur dan agama. 
Dengan demikian, persoalan utama yang menjadi fokus tulisan ini adalah terkait bagaimana nalar rasional yang mendasari pemahaman dan pemikiran generasi milenial kota Surabaya pada tema Islam Moderat dan Islam Radikal, apakah teks yang menjadi rujukan beberapa pemuda yang terhimpun dalam informasi media online benar-benar merasuk dalam pemikiran dan tindakan generasi milenial di Surabaya, bagaimana mereka mendialogkan dengan konteks mayoritas masyarakat Kota Surabaya yang moderat, toleran, dan membuka perbedaan pemikiran dengan elemen masyarakat yang lain. Pertanyaan-pertanyaan penelitian tersebut dapat dirumuskan sebagai rumusan masalah berikut; 1). Bagaimana pembacaan teks dan konteks Generasi Milenial Surabaya tentang Islam Moderat dan Islam radikal? 2). Apa yang mendasari pandangan teks dan konteks Generasi Milenial dalam menilai Islam moderat dan Islam radikal? dan, 3). Bagaimana persepsi Generasi Milenial Surabaya terhadap Pancasila dan Syariat Islam?

Kajian ini bertujuan mendeskripsikan pandangan Generasi Milenial di Surabaya di dalam memahami Islam modern dan Islam radikal secara teks maupun konteks. Kajian ini juga diharapkan memahami dasar pemikiran yang dianut oleh generasi milenial di Kota Surabaya secara teks dan konteks. Kajian ini juga diharapkan berguna untuk melakukan pemetaan pola pikir dan pola nilai yang mendasari pandangan Generasi Milenial Surabaya tentang Islam moderat atau Islam radikal sehingga diketahui dan dipahami kecenderungan pandangan pemuda urban city tersebut.

\section{Metode Kajian}

Jenis penelitian ini adalah penelitian deskriptif-kualitatif dalam bentuk penelitian lapangan (field research) dengan melibatkan pemuda yang berusia antara 18 tahun sampai 25 tahun sebagaimana ukuran yang dikeluarkan oleh UNICEF dan Kemenpora Republik Indonesia sebagai narasumber atau informan. Mereka mewakili berbagai profesi yang terlibat dalam lembaga formal maupun non formal yang berdomisili di Kota Surabaya. Oleh karena itu, teknik pengumpulan data yang digunakan antara lain:

a. Observasi yang bersifat partisipatif terhadap kelompok pemuda, organisasi keagamaan di sekolah, kampus, pada organisasi kepemudaan, remaja masjid yang tersebar di kota Surabaya.

b. Wawancara secara tidak terstruktur dan mendalam (depth interview) ke tokoh pemuda lintas agama dan profesi yang tersebar di kota Surabaya. 
c. Telaah dokumentasi berupa jurnal, buku dan hasil survei lembaga pemerintah/NGO buletin, foto yang terkait aktivitas pemuda diwilayah kota madya Surabaya.

Langkah-langkah yang dilakukan peneliti pada tahap awal antara lain; peneliti melakukan observasi awal pada organisasi pemuda, sekolah, pesantren, masjid serta ormas Islam; menentukan lokasi yang akan dipilih sebagai lokasi penelitian; melakukan identifikasi dan kualifikasi calon narasumber yang representatif dalam memberikan informasi tentang Islam moderat dan Islam serta melakukan proses perizinan ke pemerintah kota Surabaya yang dilanjutkan ke kecamatan, kantor desa, serta lembaga kepemudaan yang menjadi objek penelitian.

Lokasi penelitian ini ialah kota Surabaya terutama pada institusi sekolah, kampus, karang taruna, ormas Islam kepemudaan. Alasan penentuan kota Surabaya ialah pertama, Surabaya merupakan kota metropolis yang terbuka atas informasi dan akses jasa. Kedua, masyarakat Surabaya sangat heterogen, baik aspek etnis, agama, budaya, profesi, serta pendidikan. Ketiga, jumlah pemuda di Surabaya berjumlah 30\% dari total pendudukan kota Surabaya yang bersumber dari data BPS yang berpendidikan formal dan non formal.

Metode analisa yang digunakan dalam penelitian ini adalah direct analysis, artinya antara proses pengumpulan data serta analisa data dilakukan secara bersamaan di saat peneliti mengumpulkan data lapangan, baik di saat melakukan observasi, wawancara, maupun telaah data dokumen. Dengan demikian, hasil penelitian akan semakin akurat dan valid karena data lebih mudah untuk diolah secara langsung di lokasi, tanpa jeda masa penumpukan informasi yang terkadang berakibat kehilangan aspek kebaharuannya.

\section{Hasil dan Pembahasan}

\section{Surabaya: Entitas Keragaman Budaya dan Agama}

Kota Surabaya, yang merupakan ibu kota Provinsi Jawa Timur, adalah kota terbesar kedua di Indonesia setelah Jakarta. Kota ini terletak antara $07^{\circ} 9^{\prime}$ s.d. $07^{\circ} 21^{\prime}$ Lintang Selatan dan $112^{\circ} 36^{\prime}$ s.d. $112^{\circ} 54^{\prime}$ Bujur Timur. Wilayahnya merupakan daratan rendah dengan ketinggian 3-6 meter di atas permukaan air laut, kecuali di sebelah selatan ketinggian 25- 50 meter di atas permukaan air laut. Batas Wilayah, Sebelah Utara: Selat Madura, Sebelah Timur: Selat Madura, Sebelah Selatan: Kabupaten Sidoarjo, Sebelah Barat: Kabupaten Gresik. Luas wilayahnya seluruhnya kurang lebih 326,81 km² yang terbagi dalam 31 Kecamatan dan 154 Kelurahan (Badan Pusat Statistik Kota Surabaya: 2020, 3) 
Kota Surabaya yang terletak $796 \mathrm{~km}$ sebelah timur Jakarta, atau $415 \mathrm{~km}$ sebelah barat laut Denpasar, Bali, ini terletak di pantai utara Pulau Jawa bagian timur dan berhadapan dengan Selat Madura serta Laut Jawa, dan memiliki luas sekitar $350,54 \mathrm{~km}^{2}$ dengan penduduknya sebanyak 3,15 juta jiwa berdasarkan hasil registrasi pada tahun 2019 dengan laju pertumbuhan penduduk sebesar 2,07 persen. Sementara itu, rasio jenis kelamin Kota Surabaya pada tahun 2019 sebesar 98,88. Angka ini dapat diinterpretasikan bahwa dalam 100 penduduk perempuan terdapat 98 hingga 99 penduduk laki-laki.

Surabaya, yang merupakan kota metropolitan terbesar di provinsi Jawa Timur membentuk pluralisme budaya yang selanjutnya menjadi ciri khas kota Surabaya. Sebagian besar masyarakat Surabaya beretnis Jawa dan Madura. Di samping etnis Jawa dan Madura, di Surabaya terdapat etnis Ambon, Minangkabau, keturunan Eropa, Cina, Arab, dan lain sebagainya. Interaksi sosial di antara berbagai etnis di Kota Surabaya lebih terbuka dan saling dapat memahami. Perbedaan budaya antara satu kelompok dengan kelompok etnik lainnya terwujud atau dapat ditemukan antara lain dalam bentuk sistem nilai budaya (cultural value system) dan orientasi nilai budaya (cultural value orientation). Pada akhirnya, interaksi sosial di dalam kehidupan bermasyarakat di Kota Surabaya memperlihatkan bahwa setiap aktor yang berinteraksi memberikan pengakuan kepada kelompok-kelompok etnis dan agama lainnya dengan memposisikan dirinya ke dalam sebuah kehidupan bersama yang memiliki kesanggupan untuk memelihara identitas kelompoknya.

\section{Islam Moderat dan Islam Radikal Dalam Teks dan Konteks}

Islam moderat secara kontekstual diilustrasikan oleh Khalid abu al-Fadl sebagai seorang muslim yang tidak memperlakukan agama mereka laksana monumen yang beku, namun melakukannya lebih ke dalam suatu kerangka iman yang aktif dan dinamis, sehingga seorang muslim moderat sangat menghargai berbagai macam pencapaian yang diperoleh dari sesama muslim di masa lalu, namun mereka juga hidup di zaman sekarang. (Fadl, 2007) Sedangkan secara tekstual moderasi dalam Islam dapat ditilik pada konsep wasathiyah yang digali dari beberapa ayat dan hadis Nabi, QS. al-Baqarahm [2] :143, QS. al-Furqan, [25]:67, al-Isra, [17]:29, dan al-Isra' [17]: 110, serta dua hadis berikut:

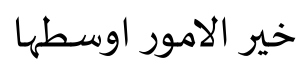

“Sebaik-baik persoalan adalah jalan tengahnya." (al-Athir, 1969) 


$$
\text { خير الاعمال اوسطها دين الله بين القاسي و الغالي }
$$

"Sebaik-baik amal perbuatan adalah tengah-tengah, dan agama Allah itu berada di antara yang beku dan yang mendidih." (as-Suyuti, 1994)

Dari beberapa ayat dan hadis Nabi di atas dapat dipahami bahwa wasat jiyah berarti jalan tengah atau keseimbangan antara dua hal yang berbeda atau berkebalikan, seperti keseimbangan antara ruh dan jasad, antara dunia dan akhirat, antara individu dan masyarakat, antara idealitas dan realitas, antara yang baru dan yang lama, antara 'aql dan naql, antara ilmu dan amal, antara usul dan furu', antara sarana dan tujuan, antara pesimis dan optimis, dan seterusnya. Jalan tengah antara dua hal yang berbeda, misalnya antara A dan B, mengandung dua pengertian. Pertama, moderat bisa berarti bukan A dan juga bukan B. konsep Islam tentang infaq, misalnya, adalah jalan tengah antara kikir (taqtir) dan boros (israf), artinya Islam mengajarkan agar pemberi nafkah tidak kikir dan juga tidak boros, melainkan berada di antara keduanya. Contoh lain yaitu konsep Islam tentang paham adalah jalan tengah di antara liberalisme dan konservatisisme, ini artinya bahwa tidak mengajarkan liberalism dan juga tidak konservativisme. Kedua, moderat juga bisa berarti bukan hanya A dan juga bukan hanya B, atau dengan kata lain ya A dan juga ya B. Islam, misalnya, adalah agama yang bukan hanya mengajarkan/ mengurusi hal-hal yang bersifat rohani dan juga bukan hanya mengajarkan/ mengurusi hal-hal yang bersifat jasmani, tetapi mengajarkan/ mengurusi keduanya, mengajarkan/ mengurusi hal-hal yang bersifat rohani dan juga mengajarkan/ mengurusi hal-hal yang bersifat jasmani. Contoh lain adalah Islam antara nas dan ijtihad. Ini berarti bahwa hukum Islam tidak hanya didasarkan pada nas semata, tetapi di banyak hal juga memerlukan keterlibatan ijtihad. Contoh lain lagi adalah Islam antara dunia dan akhirat. Ini berarti bahwa Islam bukan hanya mengatur urusan dunia dan bukan hanya mengatur urusan akhirat, melainkan mengatur keduanya, ya dunia, ya akhirat. (Muhajir, 2018)

Pada tataran praksisnya, wujud moderat atau jalan tengah dalam Islam, sebagaimana dijelaskan di atas, mewarnai ajaran akidah, ajaran akhlak-tasawuf, dan ajaran syariat, serta metodologi (minhaj) masing-masing. Moderasi dalam ajaran akidah Islam dapat dilihat pada paham ketuhanannya yang monoteisme (paham satu Tuhan). Paham ketuhanan monoteisme merupakan jalan tengah antara paham ateisme (paham tak bertuhan) dan paham politeisme (paham banyak Tuhan). Ini berarti bahwa Islam tidak menganut ateisme dan juga tidak politeisme. (Muhajir, 2018) 
Sedangkan istilah radikalisme berasal dari bahasa latin, radix, yang berarti akar. Dari akar kata tersebut, radikalisme dimaknai berpikir tentang segala sesuatu sampai mendalam hingga ke akar-akarnya. Di dalam Cambridge Advanced Learners Dictionary disebutkan radical is beleaving or expressing the beleaf that there should be great or extreme social or political change. (Cambridge Advance Learners Dictionary, 2008) Di dalam Kamus Besar Bahasa Indonesia, radikalisme memiliki beberapa pengertian berikut: a). Paham atau aliran yang radikal dalam politik, b). paham atau aliran yang menginginkan perubahan atau pembaharuan sosial dan politik dengan cara kekerasan atau drastis, c). Sikap ekstrem dalam aliran politik. (Departemen Pendidikan dan Kebudayaan, 1989)

Radikalisme biasanya juga dihubungkan dengan gerakan-gerakan ekstrem kanan. Dari pengertian tersebut, radikalisme diartikan sebagai paham yang menghendaki adanya perubahan dan pergantian terhadap suatu sistem masyarakat sampai ke akarnya. Radikalisme menginginkan adanya perubahan secara total terhadap suatu kondisi atau semua aspek kehidupan masyarakat. (Purnomo, 2009) Di samping itu, radikalisme dipahami pula sebagai transformasi dari sikap pasif atau aktivisme kepada sikap yang lebih radikal, revolusioner, ekstrem, dan militan.

Yusuf al-Qaradhawi, menyamakan istilah radikalisme keberagamaan dengan istilah at-tat\}arruf ad-di>ni>. Menurutnya radikalisme adalah paham keagamaan yang mempraktikkan ajaran agama dengan tidak semestinya, atau mempraktikkan ajaran agama dengan mengambil posisi t\}arf atau pinggir. (al-Ashmawi, 1998) Posisi pinggir adalah sisi yang berat atau memberatkan dan berlebihan serta tidak sewajarnya. Praktik keberagamaan seperti ini, menurutnya, setidaknya mengandung tiga kelemahan. Pertama, tidak disukai oleh tabiat kewajaran manusia. Kedua, tidak bisa berumur panjang. Ketiga, sangat rentan mendatangkan pelanggaran atas hak orang lain.

Sekurang-kurangnya terdapat tiga teori yang menyebabkan adanya gerakan radikal dan tumbuh suburnya gerakan transnasional ekspansif, menurut Syafi'i Ma'arif dalam Ilusi Negara Islam, Ekspansi Gerakan Transnasional di Indonesia (2009). Pertama, kegagalan umat Islam dalam menghadapi arus modernitas sehingga mereka mencari dalil agama untuk "menghibur diri" dalam sebuah dunia yang dibayangkan belum tercemar. Kedua, dorongan rasa kesetiakawanan terhadap beberapa negara Islam yang mengalami konflik, seperti Afghanistan, Irak, Suriah, Mesir, Kashmir, dan Palestina. Ketiga, kegagalan negara mewujudkan cita-cita negara yang berupa keadilan sosial dan kesejahteraan yang merata, dalam konteks Indonesia. 
Dalam suatu artikelnya, Adian Husaini mengutip dan menganalisis beberapa pendapat Samuel P. Huntington yang menulis buku berjudul "Who Are We? The Challenges to America's National Identity" pada tahun 2004, mengatakan bahwa musuh utama Barat pasca Perang Dingin adalah "Islam militan.” Namun, dari berbagai penjelasannya, definisi "Islam militan" melebar ke mana-mana, ke berbagai kelompok dan komunitas Islam, sehingga definisi itu menjadi kabur. Hal ini membuktikan bahwa Islam secara tidak langsung diciptakan (dijebak) sebagai teroris sehingga persepsi terhadap Islam pun menjadi buruk dan mengerucut bahwa Islam adalah teroris. Definisi "Islam militan” yang tanpa batasan tersebut kemudian merugikan umat Islam secara keseluruhan.

\section{Persepsi Generasi Milenial Terhadap Islam Moderat dan Islam Radikal}

\section{a. Persepsi Islam Moderat}

Persepsi Generasi Milenial Surabaya tentang Islam dapat disimak dari hasil wawancara dengan mereka dalam penelitian ini. Berbicara mengenai tema Islam moderat, mereka tidak ingin secara tekstualis mengembalikan kepada kejayaan Islam masa lalu. Mereka mengambil spirit kemajuannya, bukan mengubah secara vis a vis sebagaimana dipahami oleh teroris suci yang dikemukakan oleh David C. Rapoport yang menyebutkan bahwa teroris suci lebih melihat masa lalu atau romantisme Islam untuk diaktualisasikan di masa kini sebagai spirit perjuangan mereka. (Rapoport, 2001) Dalam wawancara, Generasi Milenial kota Surabaya mengatakan:

"ya kita kan di Indonesia itu kan beda sama di Arab, ya kita kurang setuju sama khilafah kan Islam, dulu Islam dibawa kesini dengan adatnya kita dan identitas kita sebagai orang Indonesia” (wawancara, 11 Juli 2019)

Hampir keseluruhan persepsi mereka mengarah pada pemahaman dan pengalaman keberagamaan Islam modern. Penyebutan Islam modern sesuai dengan gagasan Martin Van Bruinessen yang menyimpulkan bahwa terjadi pergeseran baik pada muslim tradisional maupun muslim modern. Muslim tradisional bergerak ke arah fleksibilitas sementara muslim modern ke arah kemapanan statis. Martin Van Bruinessens, dalam bukunya yang berjudul "Pesantren and Kitab Kuning Continuity and Change in a Tradition of Religious Learning," menyatakan bahwa pergeseran yang paling ekstrem pada Islam modern ialah pemilihan mereka pada gerakan purifikasi ajaran Islam yang condong pada purifikasi dan tekstualitas. (Marschall, 1994)

Hasil wawancara di atas mengindikasikan bahwa: 
a. Informan cenderung bersikap toleran dan masih memiliki keingintahuan tinggi.

b. Latar belakang pendidikan yang diberikan oleh orang tuanya yang cenderung tidak membatasi aktivitas informan dan lebih menekankan pada sikap disiplin.

c. Rasa keingintahuan informan terhadap kepercayaan atau agama lain yang ditunjukkan dengan cara sesekali menanyakan ajaran agama temannya yang non muslim dalam lingkungan kampus.

Hal ini sesuai dengan pandangan Durkheim bahwa agama merupakan perwujudan dari collective consciouness. Dalam wawancara, Generasi Milenial kota Surabaya mengatakan:

"Kesadaran harusnya kita yang menyesuaikan dengan sana. Bukan kebalik-balik begitu. Apalagi kalau mereka menganggap yang seperti itu menurutku Islam moderat itu yang fleksibel sih."

Hal tersebut tercermin dari persepsinya dalam menguraikan pengertian Islam moderat sebagai Islam yang seperti pada umumnya diikuti oleh masyarakat dan Islam radikal sebagai kelompok Islam garis keras. Persepsi ini juga menyiratkan bahwa Islam radikal itu bukanlah Islam yang pada umumnya ada di masyarakat. Hal ini senada dengan apa yang dikatakan Scott M. Thomas yang mengemukakan bahwa istilah radikalisme adalah hasil labelisasi terhadap gerakan-gerakan keagamaan dan politik yang memiliki ciri pembeda dengan gerakan keagamaan dan politik mainstream (pada umumnya). (Thomas, 2015)

Indikator kelompok Islam Moderat, menurut beberapa generasi milenial kota Surabaya yang sempat diwawancarai, adalah mengusung tema-tema Islam Nusantara, toleransi, dan pluralisme. Namun mereka juga melalak narasi truth claim, seperti pernyataan mereka dalam menilai Islam Nusantara sebagai berikut:

"Islam Nusantara yang paling benar itu malah parah lagi. Sangat tidak setuju ya karena semua itu bid`ah. Sudah jelas semua dalilnya. Rasul aja gak pernah kan mencontohkan seperti itu. Tapi ya walaupun sudah terlanjur jadi tradisi sebisa mungkin kita hindari. Kalau ortu atau keluaga maksa banget ya sudah biarin aja. Boleh ya karena kalau tidak dikasih contoh yang sesuai dengan pemahaman kita nanti malah ujung-ujungnya gak paham dong ya." (wawancara, 14 Juli 2019)

Pada pertanyaan ini informan memberikan jawaban sebagaimana pada umumnya remaja berusia 17 tahun yang bersekolah di sekolah umum. Di satu sisi Islam dimaknai sebagai agama yang mendorong anti kekerasan, pada sisi lain Islam membutuhkan identitas dan ketegasan. Penilaian ini didasari dari sikap mereka yang menilai pendapat peran ulama 
yang salafi itu sangat dibutuhkan karena mereka tidak bisa memahami sendiri agama tanpa ijma' ulama. Terlebih soal memilih pimpinan, seperti pada pemilihan presiden yang lalu, ijma’ ulama menyuruh umat Islam memilih Pak Prabowo.

"Hal itu harus kita ikuti. Perbedaan adalah sebuah keniscayaan dan kita tidak boleh memaksakan kehendak kebenaran pada setiap orang karena hidayah adalah milik Allah. Contohnya Islam Nusantara yang sering digembor-gemborkan itu menurut saya terlalu memaksakan kehendak. Menurut saya Islam ya Islam saja tidak perlu diberi label Nusantara. Karena Islam yang asli berasal dari Arab.”

"Saya sangat tidak setuju jika agama dijadikan dasar berbuat kekerasan karena Islam sendiri menganjurkan perdamaian. Tapi kalau FPI itu sebetulnya mereka gak melakukan kekerasan. Mereka itu berbuat sesuai yang disyariatkan Islam. Kalau mau tatanan masyarakat bagus ya memang harus ada yang seperti FPI. Kita beragama juga harus memakai pikiran, jika pemuka agama sampai menyuruh kita melupakan keluarga apalagi menjadi pelaku bom artinya diri kita yang tidak bisa memfilter ajakan mereka."

"Sebetulnya yang benar itu ya saat Islam sedang berjaya di masa lalu. Semua tatanan kehidupan bisa terjalin dengan baik. Justru modernitas yang asalnya dari Barat ini yang membuat dunia mengalami kemunduran dan ketidakadilan." (wawancara, 18 Juli 2019)

Terdapat banyak bias dalam jawaban informan kali ini. Dia menunjukkan sikap antipati terhadap Islam Nusantara dan menyebutnya sebagai Islam yang memaksakan kehendak pada yang lain. Sedangkan FPI justru disebut sebagai ormas yang benar karena mampu melaksanakan syariat Islam. Narasumber tidak menyadari bawa ada hak asasi manusia yang banyak dilanggar oleh FPI. Baik hak untuk melaksanakan ibadah sesuai dengan keyakinan maupun hak keamanan karena telah bertindak sebagai aparat hukum di luar undang-undang yang berlaku.

Pola standar ganda yang dianut oleh narasumber justru berkebalikan dengan teori standar ganda Hugh Goddrad yang menyebutkan adanya penilaian yang bersifat ideal dan normatif terhadap pemeluk agama Kristen dan Islam. Sementara penilaian realistis dan historis ditujukan pada agama lain. (Goddard, 2011) Narasumber memberikan penilaian ideal dan normatif pada aliran Islam lain, sedangkan dengan agama lain lebih bersikap realistis dan historis, Jawaban narasumber yang mengagumi masa lalu Islam sangat 
dipahami sebab pola pemaknaan Islam salafi memang lebih mengedepankan masa kejayaan Islam. Mereka mengatakan:

"Menurut saya kalau Islam radikal itu Islam yang garis keras, sementara Islam moderat itu ya Islam yang seperti pada umumnya, nggak terlalu fanatik." (wawancara, 23 Juli 2019)

Pendapat lain dari pertanyaan di atas, informan memberikan jawaban bahwa pengertian Islam moderat adalah Islam sebagaimana yang diwakili oleh ormas NU serta Muhammadiyah dan Islam radikal sebagai kelompok Islam garis keras. Yang menarik, meskipun secara tidak rinci, informan juga sedikit menjelaskan pandangannya terkait dengan ciri-ciri kelompok Islam yang menurutnya adalah bagian dari Islam Radikal. Ciri yang paling mencolok menurut informan adalah dari cara berpakaian (bagi wanita) dan isi ceramah. Karena itu, pengertian tentang Islam Radikal dan Moderat sangat tergantung siapa yang mendefinisikan. Ciri Islam Radikal yang dilabelkan oleh informan tersebut merupakan sebuah persepsi yang sifatnya subjektif.

Setiap orang mempunyai kecenderungan berbeda dalam melihat suatu hal. Perbedaan tersebut bisa dipengaruhi oleh banyak faktor, di antaranya adalah pengetahuan, pengalaman dan sudut pandang yang dimiliki kemudian berusaha untuk menafsirkannya. Informan mendapatkan pengetahuan tentang Islam moderat dan radikal dari diskusi dengan temantemannya kuliah dan membaca informasi di internet.

Setiap agama tentu terbuka untuk ditafsirkan oleh penganutnya sesuai pemahaman dan pengetahuannya masing-masing, hal ini menyebabkan lahirnya beragam perilaku dan tafisr dalam beragama. Tatkala penganut beragama membaca Kitab Suci dan mencoba memahami maka akan banyak faktor yang mempengaruhi penafsiran tersebut. Sementara tak bisa dipungkiri bahwa perilaku akan tergantung pada penafsiran. Menurut Informan, aksi-aksi kekerasan belakangan ini yang selalu mengatasnamakan agama (Islam) untuk melegitimasi tindakan mereka adalah hal yang salah dan tidak mencerminkan ajaran Islam.

Dalam pandangan mereka, Islam adalah agama yang mengajarkan tentang perdamaian dan cinta kasih bukan sebaliknya. Mereka mengatakan:

"Kita tentunya menolak setiap kekerasan atas nama Tuhan dan agama. Kita pun menolak setiap upaya untuk menjadikan agama sebagai alat demi kepentingan tertentu. Untuk itu saatnya kaum beragama menampilkan wajah agama yang 
sesungguhnya yakni wajah agama yang damai dan penuh cinta kasih". (wawancara, 11 Agustus 2019)

Setujunya informan terhadap pemerintah Surabaya yang bekerja sama dengan pemerintah asing menunjukkan bahwa informan bersikap terbuka pada modernisasi.

\section{b. Persepsi Islam Radikal}

Pemahaman informan tentang Islam radikal merupakan representasi dari common sense masyarakat pada umumnya, di samping juga merupakan representasi dari pola pendidikan orang tua informan. Apa yang diajarkan orang tua informan tentang Islam moderat dan Islam radikal menandakan bahwa ajaran itu menjadi fungsi laten yang terus dipelihara.

Narasumber pun secara gamblang meyebutkan terma Salafi. Terma Salafi kerap digunakan oleh kelompok tekstualis sebagai penyebutan identitas mereka. Secara teori ditemukan bahwa istilah Salafi yang pada masa kini merujuk pada gerakan Salafi merupakan langkah purifikasi yang ingin mengembalikan dasar-dasar kehidupan sosial, budaya dan politik berdasarkan teks wahyu. (Euben, 2002) Mereka mengatakan:

"Jihad itu berusaha di jalan yang benar yang diridhoi oleh Allah, tapi tetap sadar bahwa kita disini itu diantara beribu perbedaan. Memang kita mayoritas Islam, tapi kita harus menghormati yang lainnya. Memang harus diakui jihad dilakukan dengan cara kekerasan oleh orang Islam untuk kepentingan Islam. Masalahnya adalah ada beberapa orang yang tidak menguasai dan tidak mengerti tentang konsep jihad. Karena tidak menguasai hal tersebut, akhirnya jihad hanya dimaknai dengan cara angkat senjata. Ibu saya pernah mengatakan bahwa jangan pernah memaknai jihad sebagai bunuh diri. melakukan kebaikan setiap hari kepada orang lain juga termasuk jihad. Ibu saya juga mengatakan jihad adalah pengorbanan demi kebaikan orang lain, dalam artian saya mengebom orang lain itu bukan kebaikan. Itu selalu tertanam dalam pikiran saya sampai sekarang. " (wawancara, 15 Agustus 2019)

Lebih lanjut mereka mengatakan:

"Tafsiran tiap orang beda-beda. Jadi kayak yang diambil teks-teks tertentu, padahal tidak begitu. Ada perintah "meskipun kamu mendapatkan perlakuan buruk dari manusia tapi kamu tetaplah berbuat baik." Mungkin itu salah satu bentuk jihad mereka."

"Jihad itu membela dan berjuang terhadap masyarakat yang tertindas. Berjuang 
untuk tetap menegakkan ibadah kepada Tuhan. Jihad tidak perlu membela-bela Islam dengan cara menyakiti manusia. Aku lebih memilih jihad kepada diri sendiri untuk menegakkan dalam hati masing-masing." (wawancara, 22 Agustus 2019)

Radikalisme merupakan hasil labelisasi tentang gerakan-gerakan keagamaan yang memiliki ciri pembeda dengan gerakan Islam mainstream yang bertujuan untuk menegakkan aksi-aksi kekerasan belakangan ini yang selalu mengatasnamakan agama (Islam). Melegitimasi tindakan mereka adalah hal yang salah dan tidak mencerminkan ajaran Islam. Dalam pandangannya, Islam adalah agama yang mengajarkan tentang perdamaian dan cinta kasih bukan sebaliknya. Mereka mengatakan:

"Islam, yang menurutku radikal, menurut meraka adalah Islam yang benar-benar kukuh dengan pendiriannya. Siapa yang melanggar ketentuan atau berbeda pandangan dengan Islam, dia bukan bagian dari kelompok Islam mereka. Pasti orangorang juga akhirnya menilai bahawa Islam seperti itu. Orang Islam memiliki ideologi radikal. Aku kurang setuju sih. Dalam al-Qur'an sendiri mengajarkan kasih kepada sesama manusia. Siapa sih yang menjadi contoh mereka? Katanya mencontoh Nabi Muhammad, Nabi Muhammad sendiri baik dengan non muslim." (wawancara, 27 Agustus 2019)

Pemahaman tentang Islam moderat yang dikemukakan oleh informan tersebut merupakan pandangan keagamaan mayoritas masyarakat Indonesia

\section{Dasar Persepsi Generasi Milenial Terhadap Islam Moderat dan Radikal, Antara Teks dan Konteks}

Meskipun berada pada awal usia remaja, generasi milenial mempunyai gambaran umum mengenai Islam ideal, Senada dengan teori yang dikemukakan oleh Muslim A. Kadir mengenai Islam ideal dan Islam faktual bahwa Islam ideal adalah Islam yang universal, tidak terikat dengan ruang dan waktu. Islam ideal mewujud pada teks Alquran dan sunnah. Islam Ideal melahirkan Islam faktual sebagai sebuah respons penghayatan atas teks Alquran dan sunnah. Islam faktual merupakan dialektika agama dengan pemikiran, perilaku, dan kebudayaan pemeluknya. (Kadir, 2003)

Sumber referensi utama generasi milenial paling dominan diperoleh dari media, sosial media internet dan youtube. Media visual menjadikan terbiasa mendengarkan ceramah ustadz yang populer versi media televisi, misalkan Ustadz Abdul Shamad, Adi Hidayat dan para selebriti dengan gerakan-gerakan hijrah. Budaya pop juga memasuki ruang tata berpikir 
mereka dengan menjadikan para artis sebagai role model. Pada akhirnya, keagamaan para artis-artis yang sedang populer saja yang ia ikuti. Mereka mengatakan:

"Akhirnya saya mengikuti pengajian mereka. saya kadang buka Youtube, Instagram.

Untuk website saya jarang buka. Tapi saya agak jarang mengikuti ceramah Ustadz. Abdul Shamad. Bagi saya, penyampaian Ustadz Abdul Shamad kurang menarik. Saya lebih tertarik dengan ceramah Ustadz Adi Hidayat dan Ustadz Hanan Attaqi, terutama renungannya. Kebanyakan ceramah yang saya dengar di media lebih untuk motivasi saja sih mas." (wawancara, 30 Agustus 2019)

Ketiga narasumber termasuk pada kategori digital native ialah generasi muda masa kini yang lahir di era digital dan tumbuh di era perkembangan informasi digital. (Prensky, 2008) Informasi digital termuat dalam sosial media. Sosial media sendiri merupakan representasi yang disajikan dalam tontonan-tontonan. Berdasarkan teori ini maka tidak mengherankan jika ketiga narasumber memperoleh informasi keagamaan melalui konten di dalam sosial media. Hanya saja proses filtrasi yang belum mampu mereka identifikasikan mana konten yang benar dan tidak benar. Hal ini terbukti dengan beragamnya rujukan tokoh keagamaan yang mereka pilih untuk ditonton di Youtube.

Menurut mereka, para tokoh yang dijadikan rujukan adalah tokoh-tokoh yang diminati oleh kaum milenial dan orang-orang yang baru hijrah dan pilihan materi serta bahasa yang sederhana, ringan, dan mudah dicerna. Alasan utama kaum milenial terhadap ustadz Adi Hidayat dan Hanan Attaqi dikarenakan redaksi dakwah Adi Hidayat lebih logis dan mudah dipahami dan Ustadz Hanan Attaqi yang metode dakwahnya lebih menyentuh perasaan dan kegelisahan kaum-kaum muda.

Kekurangan informan mengakses dunia pendidikan formal membuat mereka lebih menggunakan media sosial dalam mengakses wawasan keagamaan. Apa yang diperoleh informan dari media disikapi bukan hanya sebagai informasi, tetapi juga sebagai data. Apabila media sosial digunakan dan dijadikan referensi utama oleh informan dalam memperoleh informasi dan data, hal tersebut bisa mempengaruhi pola pikir dan tindakannya. Mereka mengatakan:

"Saya mendengar Islam dari kajian yang saya ikuti di Masjid Al Falah dan dari beberapa pemberitaan di TV maupun media sosial. Saya mendapatkan pemahaman ini dari teman, buku, dan internet. Tapi untuk porsinya, saya mendapatkan pemahaman itu pertama dari teman dan kedua dari buku. Kalau saya lebih ke teman, 
kadang saya punya waktu tertentu yang membuat melamun, dari waktu melamun itu terkadang saya memikirkan suatu hal, termasuk tentang Islam moderat atau Islam radikal itu bagaimana sih." (wawancara, 3 September 2019)

Narasi ketiga narasumber di atas masuk dalam kategori awal usia remaja. Dari keseluruhan jawaban mereka masih ditemukan adanya bias dalam memersepsikan Islam moderat dan Islam radikal. Bias tersebut diurai dalam tiga poin :

1. Tindak kekerasan atas nama agama. Narasumber setuju bahkan mendukung aksi FPI yang menggunakan aksi kekerasan dalam mempraktikkan perintah amar makruf nahi mungkar. Di sisi lain mereka menyayangkan sikap Anshor saat membubarkan pengajian Felix Siauw yang dikenal getol membela HTI.

2. Sumber referensi pendakwah. Pendakwah yang dinilai ada pada kategori Islam Kanan sering mereka tonton channel pengajiannya dalam dunia maya. Sementara pada dunia nyata mereka juga mengikuti pengajian dari pendakwah Islam Moderat seperti Habib Seikh.

3. Definisi pelanggaran hukum negara dan agama. Ketiga narasumber tampak kuat saat menjawab mengenai pentingnya ideologi Pancasila dan ketidaksetujuan pendirian Negara Islam. Jawaban mereka diperkuat dari penyebutan Apel Kebangsaan yang dilakukan oleh Anshor. Namun di titik lain mereka masih menganggap pembubaran pengajian Felix Siauw adalah salah.

Bias dalam persepsi keislaman yang mereka paparkan ditentukan oleh sejarah masa lalu dan identitas keluarga mereka yang menganut ideologi NU dan Muhammadiyah. Sejarah masa lalu sebagai bekal filter pemaknaan awal akan Islam menjadikan mereka ada di posisi moderat. Namun persepsi dasar yang mereka miliki mengalami transisi. Transisi tersebut dipengaruhi oleh konstruksi sosial. Konstruksi sosial yang mendominasi terjadinya transisi ialah dari pengaruh teman atau peer group serta trend penggunaan sosial media. Transisi merupakan sebuah keniscayaan yang terjadi dalam pembentukan sudut pandang seseorang. Manusia bukan makhluk yang solid sehingga peluang untuk berkompromi atas keadaan senantiasa berlangsung. (Sen, 2016)

Latar belakang keluarga narasumber memiliki akar yang kuat pada Islam tradisionalis. Indikasinya ialah pada penyebutan asal daerah ayah dan ibu sebagai alumni pondok pesantren. Namun akar tradisionalisme tersebut mulai tersamarkan ketika narasumber masuk sekolah SDIT yang notabene memiliki pola pembelajaran tekstual-fundamental. Ditambah 
lagi dengan suasana peer group saat kuliah yang organisasi keislaman mahasiswanya banyak diwarnai oleh sayap ideologi Partai Keadilan Sejahtera (PKS). Terbukti dari penyebutan istilah liqo yang merupakan kode dari Ikhwanul Muslimin sebagai induk PKS.

Sosok yang sangat dikagumi oleh narasumber pun memiliki basis ideologi Ikhwanul Muslimin yang kuat. Hal ini tampak dari nama seorang profesor yang selalu dirujuk saat menjawab beberapa pertanyaan. Ikhwanul Muslimin faktanya memiliki gerakan pengajaran ideologi atau disebut dengan tarbiyah yang sangat kental di kampus-kampus Indonesia. Dipelopori di ITB dan berkembang ke kampus-kampus lain termasuk di tempat kuliah narasumber. Para senior atau yang disebut dengan mujahid dakwah sering diistilahkan dengan sebutan "belajar sama mbak-mbak" oleh narasumber.

Tokoh yang dijadikan rujukan oleh informan adalah tokoh-tokoh yang diminati oleh kaum milenial dan orang-orang yang baru hijrah. Informan mengaku sering mengikuti acara kajian-kajian disebabkan tema dalam forum kajian tersebut menarik dan unik seperti membahas soal cinta dan jodoh, serta karena belum pernah mengetahui soal tema kajian tersebut, sehingga informan penasaran dan ingin hadir. Alasan lain adalah karena ajakan teman-temannya, sebab teman-teman informan semasa SMA banyak yang ikut di komunitas pemuda "hijrah-hijrah" dan kajian-kajiannya. Terutama acaranya Hannan Attaki. Informan pernah dua kali menghadiri acara tersebut dan melihat antusiasme pengunjungnya sangat tinggi sampai tempat acaranya penuh dan informan tidak kebagian tempat saat hadir di situ. Banyaknya minat kaum milenial terhadap ustadz Adi Hidayat dan Hanan Attaqi dikarenakan redaksi dakwah Adi Hidayat lebih logis dan mudah dipahami.

Sedangkan ustadz Hanan Attaqi sendiri metode dakwahnya lebih menyentuh perasaan dan kegelisahan kaum-kaum muda. Banyaknya minat kaum milenial kepada Hanan Attaqi juga dikarenakan materi dakwahnya yang tidak terlalu berat dan lebih santai. Menurut informan perkembangan zaman yang sangat cepat diperlukan penyesuaian dalam semua hal. Informan berpendapat bahwa penggunaan nalar rasional dalam metode penyelesaian hukum Islam bisa diperbolehkan, selama hal itu harus didasarkan pada apa yang telah ditentukan Allah dalam al-Qur'an, Hadits. Di antara mereka menceritakan:

"Awalnya saya mendapatkan pengetahuan agama dari kedua orang tua dan guru di sekolah SDIT. Dasar-dasar agama tersebut sangat penting semisal keharusan untuk memakai hijab. Apalagi kedua orang tua saya memiliki basis agama yang kuat. Ayah berasal dari Jombang yang kuat Muhammadiyahnya sementara Ibu meskipun asli Surabaya adalah lulusan pesantren Jombang. Namun dasar agama saja ternyata 
belum cukup. Praktik agama terasa hanya di kulitnya saja. Saat kuliah saya mengikuti liqo'. Liqo' itu semacam kajian yang diisi oleh mbak-mbak senior kampus. Melalui liqo' saya menemukan hakikat beragama. Selanjutnya sumber referensi agama saya adalah kelas kuliah Quran dan Sains yang ada di masjid Al Falah bersama Profesor Fuad. Saya juga suka melihat kajian yang ada di Youtube, tapi menurut saya berdasarkan pendapat Ustadz Salim A. Fillah, mengaji itu lebih baik secara langsung hadir. Dengan kehadiran kita memperoleh adabnya kepada guru sekaligus belajar tawadhu dari seorang guru. " (wawancara, 6 September 2019)

Dari wawancara tersebut dipahami bahwa latar belakang keluarga narasumber memiliki akar yang kuat pada Islam tradisionalis. Indikasinya ialah pada penyebutan asal daerah ayah dan ibu sebagai alumni pondok pesantren. Namun akar tradisionalisme tersebut mulai tersamarkan ketika narasumber masuk sekolah SDIT yang notabene memiliki pola pembelajaran tekstual-fundamental. Ditambah lagi dengan suasana peer group saat kuliah yang organisasi keislaman mahasiswanya banyak diwarnai oleh sayap ideologi Partai Keadilan Sejahtera (PKS). Terbukti dari penyebutan istilah liqo yang merupakan kode dari Ikhwanul Muslimin sebagai induk PKS.

Di era digital, media sosial dan internet menjadi sahabat sekaligus tempat bertanya bagi anak muda dalam belajar agama. Mereka umumnya menyukai tokoh agama yang friendly karena mereka dapat mengakses ceramah ataupun tausiahnya secara mudah di mana pun dan kapan pun mereka menginginkannya serta karena gaya bahasanya gampang diterima. Hal serupa juga dialami oleh informan lain yang menyatakan bahwa dia sering mencari rujukan dan referensi agama melalui internet (dengan cara browsing dan tanya Google), lalu website yang muncul paling atas itu yang di klik, serta menonton tausiah keagamaan melalui Instagram. Secara umum pengaruh media sosial relatif signifikan mengurangi peran pendidikan agama dalam keluarga dan peran guru agama di sekolah. Media sosial ibarat dua sisi mata uang, di satu sisi dapat digunakan untuk menyebarkan informasi dan pengetahuan yang bermanfaat dan produktif. Namun di sisi lain, ia dapat juga dipakai untuk tujuan-tujuan menebarkan hasutan kebencian dan provokasi. Dalam konteks radikalisasi paham keislaman, beberapa hasil penelitian telah menyatakan bahwa media sosial adalah media yang efektif digunakan untuk menyebarkan propaganda ideologi radikal. Menariknya, keterangan dari informan ini meskipun mengaku sering menonton ceramah Hannan Attaki, Ustadz Abdul Somad, dan Felix Siauw di Instagram, dia juga mengaku senang mengikuti postingan dari akun Instagram ala-NU dan Banser. Hal ini sebenarnya 
lumrah terjadi pada remaja dan anak muda yang sedang dalam proses pencarian identitas diri. Dalam fase ini seorang remaja biasanya cenderung masih labil dan belum memiliki pendirian yang kokoh, namun memiliki rasa ingin tahu yang tinggi, bersemangat mengumpulkan informasi, melakukan penyimpulan dan pada puncaknya pembentukan karakter. Salah satu faktor yang mempengaruhi mereka adalah proses meniru atau imitasi seorang remaja terhadap orang lain yang dianggapnya ideal.

Dari penuturan informan tersebut, sosok penceramah yang cocok untuk anak muda diwakili oleh Felix Siauw dan artis-artis hijrah yang sekarang menjadi pendakwah seperti Teuku Wisnu dan Niko al-Hakim. Media Sosial sudah menjadi sahabat sekaligus tempat bertanya bagi anak muda dalam belajar agama. Mereka umumnya menyukai tokoh agama yang bisa menyesuaikan dengan gaya hidup dan kebutuhan anak muda serta gaya bahasa dalam penyampaian ceramahnya gampang dicerna dan tidak ribet.

Ketika ditanya tentang interpretasi tekstual dan kontekstual dan tekstual, mana yang harus diutamakan, informan menjawab:

"Harusnya fleksibel, tapi lihat fleksibelnya bagaimana dulu. Peran ulama penting, tapi tidak ada sertifikasi ulama. Semua orang bisa jadi ulama. Saya kemarin membaca twitt dari anak Gus Dur yang mengatakan bahwa seorang habib harus mencintai dan dicintai, dan harus bisa ngaji dan tidak menyebar kebencian dan tidak dibenci oleh umat. Menurut saya, Islam masuk Jawa dalam bentuk budaya seperti wayang dll. Sebenernya, agama dan budaya itu bisa satu, tapi juga perlu dilihat konteksnya. Seperti nyekar, ada yang bilang itu bentuk penyembahan. padahal tidak seperti itu, kan cuman sekedar mendoakan. (wawancara, 8 September 2019)

Cara pandang generasi milenial mempengaruhi tindakan sosial mereka yang semakin moderat pandangan hidupnya. Tindakan sosial berbanding lurus dengan perspektif generasi milenial. Implementasi antara worldview dengan world life dapat dilihat dari hasil wawancara tentang toleransi. Toleransi intra dan inter-religius yang dipahami oleh narasumber berada pada tingkat pluralisme yang baik. Sesuai dengan kategori yang disampaikan oleh Komarudin Hidayat, mereka membenarkan ajaran agama dan aliran agamanya secara absolut namun tidak menyerang aliran maupun agama lain secara frontal. (Hidayat, 2008)

Hanya saja mereka menganggap bahwa ajaran aliran maupun agama lain tidak seutuhnya benar. Hal ini tampak dari ketidaksediaan mereka saat diajak untuk melakukan 
ritual di luar apa yang mereka yakini. Dalam perkara mengucapkan selamat hari raya kepada teman yang beda agama, informan juga tampak lebih menunjukkan toleransinya. Dia berpendapat:

"Kalau ditinjau dari pandangan sosial ya boleh-boleh saja mengucapkan selamat hari raya kepada teman yang beda agama guna mempererat tali persaudaraan saja. (wawancara, 12 September 2019)

Dalam menyikapi perbedaan antar agama, narasumber lebih bersifat moderat. Namun ketika menyebutkan perbedaan antar aliran dalam Islam, narasumber menunjukkan gesture mengernyitkan muka dengan serius. Artinya narasumber tidak terlalu menyetujui adanya perbedaan aliran dalam Islam. Narasumber menempatkan posisi toleransi intra agama secara eksklusif sesuai dengan organisasi mahasiswa yang diikuti oleh narasumber yang berafiliasi dengan PKS serta pengakuan identitas narasumber yang menyebutkan dirinya sebagai seorang salafi. Oleh karena itu, penolakan atas Pancasila menjadi logis.

Sesuai dengan pendapat Din Wahid yang membagi kelompok salafi ke dalam tiga bagian, yakni salafi puris, salafi haraki, dan salafi jihadi. Salafi puris melakukan purifikasi pada taraf pemikiran agar muslim kembali pada teks keagamaan. Salafi haraki berada selangkah di depan salafi puris karena membawa pemikiran purifikasi kepada praktik gerakan sosial politik. Salafi haraki ingin syariat Islam ditegakkan dalam kehidupan nyata. Sementara salafi jihadi yaitu gerakan perjuangan untuk mendirikan tata kelola negara dan pemerintahan sesuai dengan syariat Islam. Baik salafi haraki maupun salafi jihadi memiliki kecenderungan untuk mengubah sistem yang ada dalam negara. (Wahid, 2014) Narasumber pun berada pada kategori tersebut.

Pendirian negara berbasis agama merupakan titik tolak dari ketidaksetujuan atas bentuk pemerintahan demokratis barat. Atas dasar inilah muslim salafi menempatkan diri sebagai oposan pemerintah. Muslim salafi memiliki lima tipe gerakan perlawanan. Fight back atau melakukan perlawanan balasan, fight for berjuang untuk memperjuangkan sesuatu, fight with yakni berjuang dengan menggunakan nilai tertentu, fight agains atau berjuang untuk melawan musuh tertentu, dan fight under yaitu perjuangan atas nama Tuhan. (Effendy \& Prasetyo, 1998)

Dalam konteks kehidupan berbangsa dan bernegara, informan cenderung tidak setuju kalau pancasila digantikan dengan ideologi agama. Namun, dia menggarisbawahi bahwa untuk dirinya sendiri sebagai muslim, dia lebih cenderung mengutamakan hukum Islam. 
Jadi, terlihat bahwa pengetahuan mengenai Indonesia yang majemuk, membuat kaum muda Muslim paham bahwa sebagai konsekuensinya, ideologi dan sistem kenegaraan harus dibuat dan dikelola berdasarkan kondisi tersebut.

Terdapat banyak bias dalam jawaban narasumber kali ini. Dia menunjukkan sikap antipati terhadap Islam Nusantara dan menyebutnya sebagai Islam yang memaksakan kehendak pada yang lain. Sedangkan FPI justru disebut sebagai ormas yang benar karena mampu melaksanakan syariat Islam. Narasumber tidak menyadari bahwa ada hak asasi manusia yang banyak dilanggar oleh FPI. Baik hak untuk melaksanakan ibadah sesuai dengan keyakinan maupun hak keamanan karena telah bertindak sebagai aparat hukum di luar undang-undang yang berlaku.

Pola standar ganda yang dianut oleh narasumber justru berkebalikan dengan teori standar ganda Hugh Goddrad yang menyebutkan adanya penilaian yang bersifat ideal dan normatif terhadap pemeluk agama Kristen dan Islam. Sementara penilaian realistis dan historis ditujukan pada agama lain. (Goddard, 2011) Narasumber memberikan penilaian ideal dan normatif pada aliran Islam lain sedangkan dengan agama lain lebih bersikap realistis dan historis

Dalam hal melihat perbedaan madzhab dalam Islam, informan menjawab dengan diplomatis. Dia menganggap bahwa setiap orang memiliki sumber pemahaman atau guru yang berbeda-beda, jadi lumrah dan mempersilahkan setiap orang untuk memiliki perbedaan dalam beragama. Atau dalam pemahaman kami, informan memiliki pandangan bahwa perbedaan itu tidak dapat disatukan sehingga yang bisa dilakukan hanya saling memahami dan bersikap toleran. Toleransi dalam muamalah bisa diterima jika baik dan benar.

Informan menyatakan bahwa perbedaan paham dalam menjalankan ritual keagamaan adalah hal yang niscaya, asalkan dalam praktiknya tidak saling menyalahkan kepercayaan masing-masing. Dalam hal ini informan dapat dikatakan agak cuek dan cenderung individualis apabila menyangkut hak dan kebebasan individu. Ketika informan disuguhkan pada pertanyaan terkait isu-isu seperti ucapan selamat hari raya kepada umat non-muslim, informan cenderung toleran. Hal ini memperlihatkan bahwa cara pandang informan sangat dinamis. Terjadi proses rasionalisasi yang dilakukan informan dengan alasan toleransi kepada teman serta rasa sungkan, apalagi kalau itu teman dekat, demi menjaga relasi pertemanan tetap berlanjut. Meskipun informan pernah mendapatkan informasi bahwa mengucapkan selamat hari raya kepada teman yang beda agama itu dilarang dalam Islam. 
Secara umum sikap dan jawaban informan dalam merespons pertanyaan soal Pancasila dan tawaran ideologi alternatif, dalam hal ini ideologi Islam bisa dikategorikan sangat nasionalis, dengan menjelaskan bahwa Indonesia adalah negara yang terdiri dari banyak agama, bukan hanya satu agama, dan menurutnya, semua agama di Indonesia sudah terwadahi dalam Pancasila. Pandangan seperti itu, memperlihatkan bahwa informan menyadari Pancasila merupakan satu-satunya ideologi dan dasar negara yang harus ditopang seluruh warga Negara apa pun agamanya, karena dengan Pancasila dapat merekatkan segenap warga bangsa yang majemuk ini.

Pada umumnya remaja dengan usia 17 tahun biasanya masih awam dengan banyak hal, utamanya dengan kebijakan pemerintah, kecuali kebijakan tersebut memiliki imbas langsung kepada mereka, seperti kebijakan tidak menggratiskan lagi SPP bagi SMAN/SMKN di Surabaya. Informan menilai bahwa kerja sama pemerintah Surabaya yang notabene dipimpin oleh muslim dengan pihak lain yang non-muslim adalah hal yang lumrah, selama itu berimbas positif bagi kemajuan daerah. Manusia adalah makhluk sosial yang selalu membutuhkan manusia lainnya dalam bekerja sama dibanyak bidang. Kerja sama yang dilakukan para pemimpin pemerintah ini biasanya didasari oleh faktor bahwa kerja sama dengan Negara atau pihak non-muslim dalam hal pengembangan teknologi, kesehatan, sosial, dan ekonomi itu akan membawa dampak positif bagi perkembangan daerahnya. Faktor lainnya adalah anggapan, bahwa non-Muslim memiliki semangat kerja lebih tinggi, sehingga sebagian besar mereka memiliki taraf sosial ekonomi, inovasi, dan pengembangan teknologi yang tinggi pula. Hal ini juga senada dengan yang dikatakan informan Yaitu kecenderungan pemahaman yang tertutup dan mencerminkan karakter yang absolutis serta tidak mau berkompromi dengan pemikiran atau tafsir lain dalam memahami agama, serta mengabaikan kontekstualitas dan bersikap anti kepada lokalitas.

Dalam menyikapi tradisi Islam yang bersumber dari budaya lokal, Informan menganggap bahwa tradisi Islam yang bersumber dari budaya lokal bisa dijadikan sebagai bagian dari dakwah Islam, asalkan tradisi tersebut sudah mengalami modifikasi dengan masuknya unsur-unsur agama Islam dalam tradisi tersebut. Dengan kata lain budaya itu mengandung unsur yang tidak dilarang dalam agama Islam. Dengan demikian, Islam yang bercampur dengan budaya lokal bisa dikatakan adalah gejala normal dari dinamika umat Islam di perkampungan Surabaya.

Ketika informan disuguhkan pada pertanyaan terkait isu-isu seperti ucapan selamat hari raya kepada umat non-muslim, informan cenderung toleran. Hal ini memperlihatkan 
bahwa cara pandang informan sangat dinamis. Terjadi proses rasionalisasi yang dilakukan informan dengan alasan toleransi kepada teman serta rasa sungkan, apalagi kalau itu teman dekat, demi menjaga relasi pertemanan tetap berlanjut. Meskipun dalam beberapa kesempatan, menurut informan, dia pernah mendapatkan informasi bahwa mengucapkan selamat hari raya kepada teman yang beda agama itu secara umum sikap dan jawaban informan dalam merespons pertanyaan soal Pancasila dan tawaran ideologi alternatif, dalam hal ini ideologi Islam bisa dikategorikan moderat, meski yang bersangkutan dalam hal memilih pemimpin cenderung memihak kepada yang seagama, dan tidak akan memilih pemimpin/kepala daerah yang non-muslim. Hal ini dimungkinkan karena pemahaman informan terhadap Pancasila sebagai keyakinan kolektif

Ya pernah sih dialog dengan agama lain seperti masalah Yesus dll. Dari situ saya paham tentang ajaran-ajaran agama lain, Cuma saya tidak mau bertanya lebih detail tentang kepercayaan mereka, takutnya nanti saya malah menyinggung. " (wawancara,

15 September 2019)

Apa yang dilakukan informan dengan tidak menanyakan perihal kepercayaan teman non muslimnya dengan lebih lanjut karena ditakutkan menyinggung menggambarkan bahwa informan mempunyai sifat toleran. Selain itu hal ini menandakan bahwa tindakan yang diambil oleh informan bersifat logis, karena informan ingin mengetahui perihal Yesus langsung pada umatnya.

"Menurut saya, jika ada kelompok atau pihak yang ingin mengganti Pancasila dengan ideologi lain itu adalah hal yang bodoh. Menurut saya, Pancasila adalah landasan tanpa batasan. Dalam sila pertama, hanya disebutkan menyembah Tuhan yang Maha Esa, namun tidak dijelaskan Tuhan yang mana. Dalam sila kedua, kita tahu bahwa dalam sila kedua hal tersebut ideologi Pancasila menawarkan kemanusian yang adil dan beradab. Saya belum pernah mengetahui bahwa ada landasan yang menawarkan jargon seperti itu selain Pancasila. Dalam sila ketiga, meskipun kita mempunyai pemahaman yang berbeda tentang suatu hal, selama kita bersatu itu tidak masalah. Intinya kita diberi kebebasan berbeda pendapat namun selama itu dalam koridor persatuan tidak masalah. Dalam sila keempat, kita tahu secara jelas bahwa negara kita adalah negara demokrasi. Dalam sila itu, kita bebas berpendapat, namun harus tetap ada musyawarah dan diskusi. Sila yang kelima sudah jelas kan.

Saya sependapat dengan Febrian, namun ada hal yang sering diangkat dalam setiap isu, yakni keadilan, padahal menurut saya keadilan hukum kita baik-baik saja. Setiap 
orang berpendapat atau bersuara tidak ditangkap, yang jadi masalah adalah saat orang-orang sering memanfaatkan kata keadilan untuk kepentingan mereka sendiri. Demo saja diperbolehkan, tidak masalah, asal kita memenuhi prosedur perijinan untuk itu. Karena yang mempunyai negara ini bukan kelompok tertentu, namun milik kita bersama, jadi kita harus menaati prosedur yang ada demi kepentingan bersama. Memang ada beberapa kelompok yang meneriakkan keadilan, seakan-akan mereka ditindas, padahal mereka semena-mena. Bagi saya ukuran kebenaran adalah yang diakui oleh khalayak umum. Misalkan saya menganggap suatu hal benar, namun orang banyak mengatakan salah ya saya yang salah. Jadi saya menganggap bahwa apa yang bermanfaat bagi orang lain ya saya ikuti. Dalam beragama saya lebih ke konsep moral individu sih, contoh kayak berjilbab, ada beberapa wanita yang berjilbab namun masih menampakkan lekuk tubuh, namun ada yang tidak berjilbab namun pakaiannya sopan, lebar. Sama sih, saya sependapat dengan Febrian. Saya sih lebih jika kebenaran itu diakui oleh masyarakat maka hal itu dianggap benar. Seтиa kembali ke mayoritas. Namun ada kebenaran yang bukan hanya dari mayoritas, katakan Pancasila, meskipun ada yang menentang tapi Pancasila adalah hal yang telah disepakati. Dalam beragama apa pun, jika kita mempunyai penafsiran yang berbeda dengan mayoritas kita tidak bisa berkutik, kita tidak bisa memaksakan penafsiran pribadi kita ke orang lain

Sikap masa bodoh karena saya ini sebenernya masa bodo, kamu mau jadi ekstrimis yaudah selama tidak mengganggu urusan orang lain, mau kamu menginginkan negara khilafah tapi selama tidak mengganggu, walaupun agak gak setuju juga. walaupun benar juga khilafah dengan hukum Islam namun tidak bisa dipukul rata kan negara kita beraneka macam kepercayaan. karena saya ini sebenernya masa bodo, kamu mau jadi ekstrimis ya udah selama tidak mengganggu urusan orang lain, mau kamu menginginkan negara khilafah tapi selama tidak mengganggu, walaupun agak gak setuju juga. (wawancara, 17 September 2019)

Meskipun informan mengikuti acara keagamaan lain secara aksidental, namun pemahaman informan mencerminkan prinsip toleransi positif, di mana informan tetap mengikuti upacara keagamaan agama lain tanpa mengorbankan nilai-nilai yang informan percayai. Islam kan masuk Jawa dalam bentuk budaya seperti wayang dll., sebenarnya agama dan budaya itu bisa satu. Informan mengamini bahwa agama dan budaya bisa saling 
membaur, secara tidak langsung informan mengamini akulturasi budaya, bahwa ada beberapa nilai esensial dalam budaya yang selaras dengan nilai agama.

\section{Penutup}

\section{Kesimpulan}

Dari pembahasan di atas maka dapat ditarik kesimpulan sebagai berikut. Pertama, Generasi Milenial mempersepsikan Islam Moderat adalah Islam yang adaptasi terhadap perubahan masyarakat modern, budaya lokal, serta tidak menggunakan agama sebagai justifikasi politik dan ekonomi, sedangkan Islam Radikal adalah Islam yang intoleran, tidak fleksibel, serta bersifat kaku terhadap perubahan. Kedua, Generasi Milenial menggunakan media internet dan media sosial sebagai rujukan referensi sekaligus role-model dalam pemahaman dan tindakan beragama, terutama para artis hijrah dan ustad gaul. Terakhir, Generasi Milennial Surabaya menerima Pancasila sebagai ideologi negara sekaligus menyaratkan negara menjalankan syariat islam.

\section{Saran}

Dengan hasil penelitian ini, disarankan bahwa perlu penelitian lebih lanjut mengenai persepsi dan perilaku Generasi Milenial yang sangat dinamis di berbagai wilayah di Indonesia, baik terhadap ideologi keagamaan dan ideologi kebangsaan, sehingga diperoleh pemahaman yang utuh terhadap persepsi dan perilaku Generasi Milenial tersebut. Pemerintah perlu mencermati berbagai hasil penelitian semacam ini yang kemudian bisa dijadikan pertimbangan dalam membuat kebijakan yang tepat dan sesuai dengan persepsi dan perilaku Generasi Milenial ter-update terhadap kehidupan berbangsa dan bernegara serta ideologi kebangsaan. Para tokoh agama juga perlu memahami perkembangan sebagaimana hasil penelitian semacam ini, sehingga mereka dapat memberikan pengajaran agama dan melakukan dakwah sesuai dengan dinamika persepsi dan perilaku Generasi Milenial terhadap keberagamaan dan ideologi keagamaan.

\section{Daftar Pustaka}

al-Ashmawi, M. S. (1998). Againts Islamic Extremism: the Writings of Muhammad Said al-Ashmawi. Florida: University Press of Florida.

al-Athir, I. (1969). Ja>mi' Us\} $u>l f i$ Ah $\} a>d i>t h$ ar-Rasu>l. Maktabah Dar al-Bayan. as-Suyuti, J. (1994). Ja>mi' $a l-A h\} a>d i>t h$ ar-Rasu $>l$. Bairut: Dal al-Fikr.

Cambridge Advance Learners Dictionary. (2008). Singapore: Cambridge University Press. 
Departemen Pendidikan dan Kebudayaan. (1989). Kamus Besar Bahasa Indonesia. Jakarta: Balai Pustaka.

Effendy, B., \& Prasetyo, H. (1998). Radikalisme Agama. Jakarta: PPIM-IAIN.

Euben, R. L. (2002). Musuh dalam Cermin Fundamentalisme Islam dan Batas Rasionalisme Modern. Jakarta: Serambi.

Fadl, K. A. (2007). Selamatkan Islam dari Muslim Puritan. Jakarta: Serambi.

France, A. (2007). Understanding Youth in Late Modernity. New York: Open University Press.

Goddard, H. (2011). Menepis Standar Ganda Membangun Saling Pengertian Muslim Kristen. Yogyakarta: Qolam.

Hidayat, K. (2008). Atas Nama Agama: Wacana Agama dalam Dialog Bebas Konflik. Bandung: Pustaka Hidayah.

Kadir, M. A. (2003). Ilmu Islam Terapan Menggagas Paradigma Amali dalam Agama Islam. Yogyakarta: Pustaka Pelajar.

Lembaga Kajian Islam dan Perdamaian (LKIP). (2011). JAKARTA: LKIP.

Marschall, W. (1994). Text from the Island Oral and Written Tradition of Indonesia and the Malay World. Virginia: University of Berne.

Muhajir, A. (2018). Memahami Fenomena Revivalisme Islam Radikal Kontemporer. Jurnal Pemikiran Islam.

Pilcher, J. (1993). Mannheim's Sociology of Generations: an Undervalued Legacy. New York: Routledge.

Prensky, M. (2008). Digital Natives Digital Immigrants. Horizon MCB University, Vol. 9, No. 5.

Purnomo, A. (2009). Ideologi Kekerasan; Argumen Teologis Sosial Radikalisme Islam. Yogyakarta: Pustaka Pelajar.

Rapoport, D. (2001). Inside Terrorist Organizations. London: Frank Cass.

Sen, A. (2016). Identitiy and Violence the Illusion of Destiny. London: Penguin Books.

Thomas, S. M. (2015). The Global Resurgence of Religion and the Transformation of International Relation, The Struggle for the Soul of the Twenty First Century. New York: Palgrave Macmillan.

Wahid, D. (2014). Nurturing the Salafy Manhaj a Study of Salafi Pesantren in Contemporary. Belanda: Utretch University. 